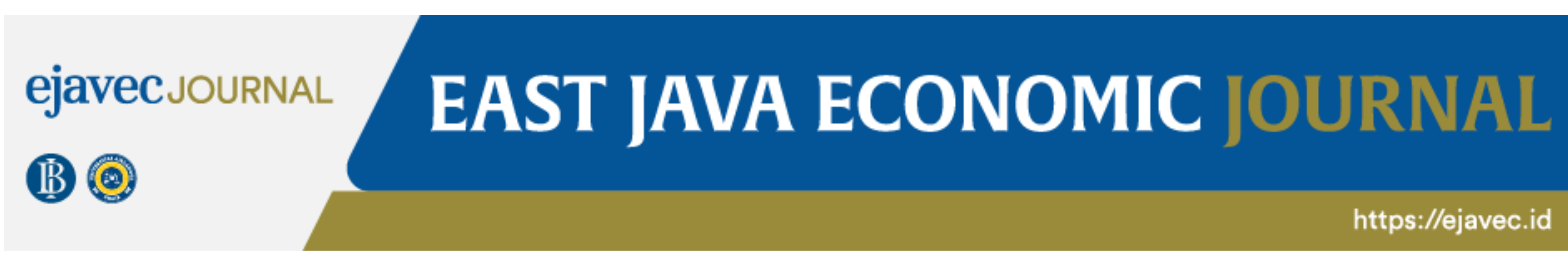

\title{
PERKEMBANGAN EKONOMI, INFLASI, DAN STABILITAS SISTEM KEUANGAN PROVINSI JAWA TIMUR SEMESTER I - 2018
}

\author{
Tim Penulis Laporan, Kantor Perwakilan Bank Indonesia Provinsi Jawa Timur
}

\begin{abstract}
Perekonomian Jawa Timur pada semester I 2018 sedikit melambat dibandingkan semester sebelumnya, namun diiringi dengan rendahnya tekanan inflasi Indeks Harga Konsumen (IHK) dan stabilnya sistem keuangan daerah. Perlambatan pertumbuhan ekonomi Jawa Timur terutama disebabkan oleh belum kuatnya kinerja ekspor luar negeri. Dari sisi perkembangan inflasi, rendahnya inflasi disebabkan oleh penurunan inflasi kelompok administered price dan core inflation dibandingkan paruh kedua 2017 seiring dengan hilangnya base effect kenaikan tarif dasar listrik di tahun 2017. Lebih lanjut, terjaganya stabilitas keuangan daerah tercermin dari masih positifnya pertumbuhan kredit, terjaganya rasio Non Performing Loan (NPL) di kisaran 3\%, serta masih kuatnya kinerja sektor korporasi dan sektor Rumah Tangga di Jawa Timur. Pada semester II 2018, kinerja ekonomi Jawa Timur diperkirakan tetap tumbuh tinggi seiring dengan perkiraan peningkatan konsumsi swasta dan kinerja net ekspor antar daerah sebagai dampak adanya momen Natal dan Tahun Baru. Inflasi IHK Jawa Timur pada semester II 2018 diperkirakan sedikit meningkat dibandingkan pencapaian pada paruh pertama 2018, dengan peningkatan bersumber dari kelompok volatile food dan core inflation. Meskipun meningkat, namun inflasi Jawa Timur diperkirakan tetap dalam batas sasaran inflasi 3,5\%+1\% seiring dengan terjaganya pasokan dan intensifnya upaya pengendalian inflasi. Dari sisi stabilitas keuangan daerah dan kinerja perbankan Jawa Timur, kinerja pada semester II 2018 diperkirakan tetap baik dengan risiko kredit dan risiko likuiditas yang tetap terjaga.
\end{abstract}

\section{Pertumbuhan Ekonomi Makro Regional}

Kinerja ekonomi Jawa Timur pada paruh pertama 2018 tumbuh sebesar 5,53\% (yoy) melambat dibandingkan paruh kedua 2017 yang tumbuh sebesar 5,68\% (yoy). Dari sisi permintaan, perlambatan disebabkan oleh investasi, ekspor luar negeri dan net ekspor antar daerah. Sementara dari sisi sektoral, kinerja sektor pertanian, transportasi dan pergudangan, serta pengadaan listrik dan gas yang tidak sekuat semester sebelumnya menjadi sumber utama perlambatan. Perlambatan ekonomi Jawa Timur yang lebih dalam tertahan oleh tingginya pertumbuhan konsumsi swasta dan pemerintah dari sisi permintaan, serta sektor industri pengolahan dan perdagangan dari sisi penawaran.

\section{Sisi Permintaan}

Deselerasi investasi, ekspor luar negeri dan net ekspor antar daerah menjadi sumber perlambatan pertumbuhan ekonomi pada semester I 2018. Pada periode ini, investasi tumbuh 5,60\% (yoy), lebih rendah dibandingkan semester II 2017 yang tumbuh sebesar 6,55\% (yoy). Perlambatan tersebut tercermin dari tingkat penjualan semen yang selama semester I 2018 turun 15,70\% (yoy), jauh lebih rendah dibandingkan semester sebelumnya yang masih tumbuh 17,06\% (yoy). Realisasi belanja modal pemerintah Provinsi Jawa Timur juga masih relatif rendah yaitu sebesar 24,02\% untuk APBD Provinsi, 11,52\% untuk APBD Kabupaten/ Kota dan 17,04\% untuk APBN yang dialokasikan di Jawa Timur. Meskipun melambat, namun

East Java Economic Journal, p-ISSN: 2597-8780, Open access undera Creative Commons Attribution- 4.0 International Public License (CC BY 4.0$)$ (C) (7)

Published by Kantor Perwakilan Bank Indonesia Provinsi Jawa Timur in Collaboration with Faculty of Economics and Business,

Universitas Airlangga 
pertumbuhan investasi di Jawa Timur masih tetap tinggi seiring dengan masih berlanjutnya proyek-proyek infrastruktur pemorintsh 11

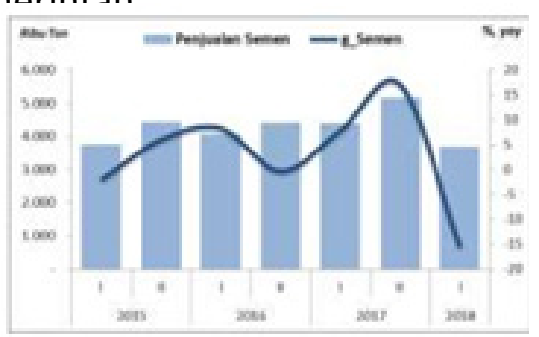

Grafik 1 Indikator Penjualan Semen

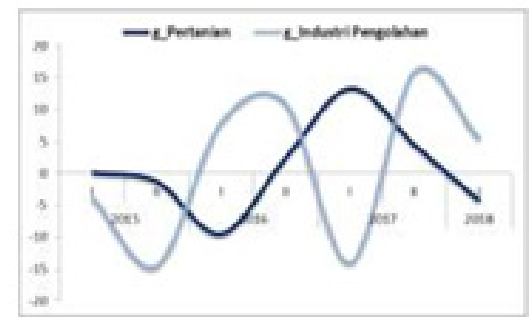

Grafik 2 Pertumbuhan Ekspor Utama Jatim

Perlambatan pertumbuhan ekonomi juga disebabkan oleh rendahnya kinerja ekspor luar negeri (dari 8,33\%,yoy menjadi 3,82\%,yoy) dan net ekspor antar daerah (dari $29,25 \%$,yoy menjadi 13,33\%,yoy). Pada semester I 2018, ekspor sektor pertanian dan sektor industri pengolahan turun. Turunnya ekspor industri pengolahan (dari 15,85\%,yoy menjadi 5,35\%,yoy) diindikasikan karena mayoritas produksi digunakan untuk memenuhi kebutuhan domestik. Akhir semester I 2018 merupakan titik awal puncak konsumsi masyarakat Jawa Timur seiring dengan adanya Ramadhan dan Idul Fitri, sehingga industri lebih memprioritaskan penjualan domestik.

Tabel 1 Pertumbuhan Ekonomi Sisi Permintaan (\%,yoy-Tahun Dasar 2010)

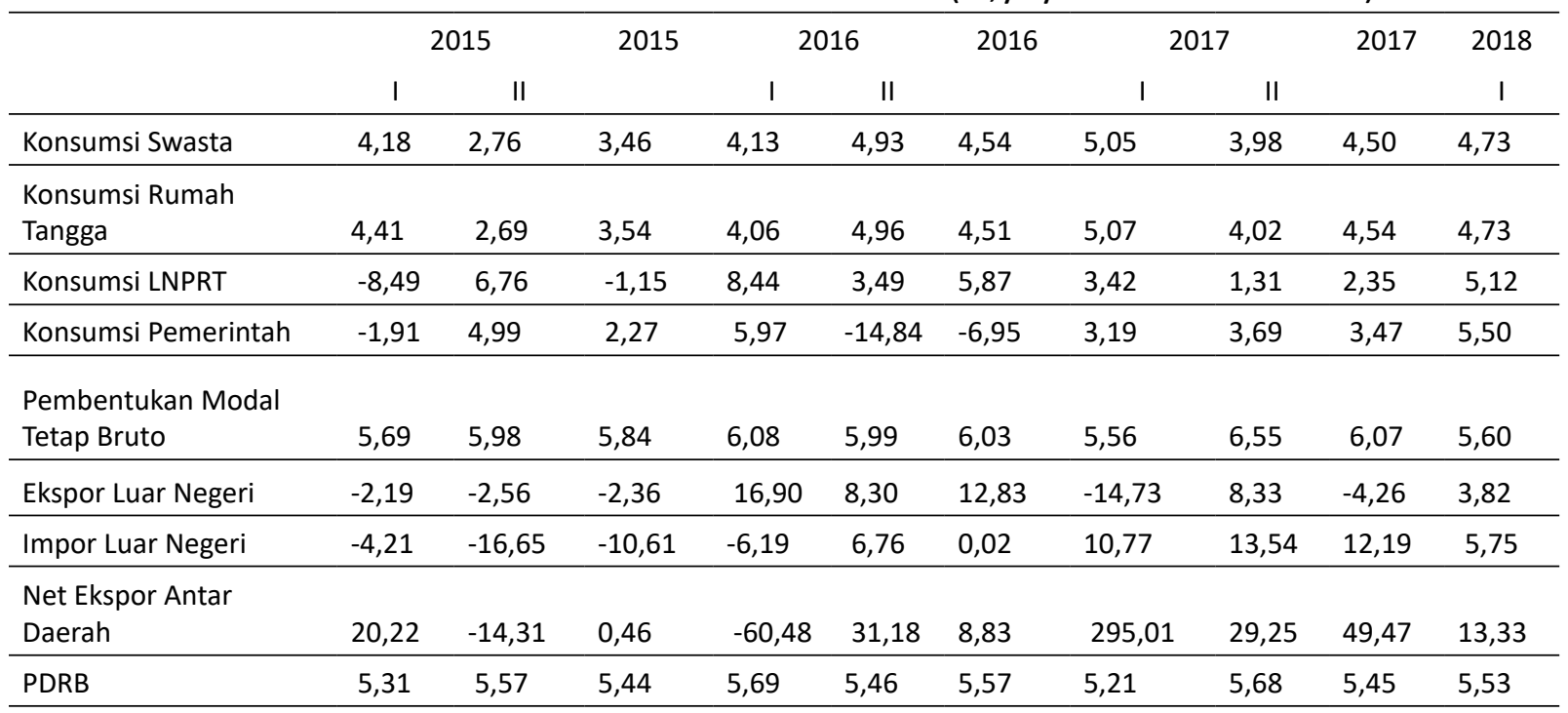

Tingginya kinerja Konsumsi Swasta menahan perlambatan ekonomi Jawa Timur yang lebih tinggi. Konsumsi swasta tumbuh sebesar 4,73\% (yoy) pada paruh pertama 2018,

\footnotetext{
${ }^{1}$ Proyek-proyek infrastruktur yang berlangsung antara lain (i) Jalan Tol Mantingan-Kertosono dengan panjang $124,4 \mathrm{~km}$ dengan target selesai 2018 (ii) Jalan Tol Kertosono-Mojokerto dengan panjang 41,5 km dengan target selesai 2018; (iii) Jalan Tol Pandaan-Malang dengan panjang 36,7 km dan target selesai pada 2018; (v) Jalan Tol Gempol-Pasuruan dengan panjang 34,2 km dan target selesai 2018; dan (iv) Jalan Tol Pasuruan Probolinggo dengan panjang $31,3 \mathrm{~km}$, (vi) pengembangan Bandara Juanda, (vii) dan pengembangan Bandara Blimbingsari.
} 
meningkat dibandingkan semester II 2017 yang hanya tumbuh 3,98\% (yoy). Peningkatan konsumsi swasta dan rumah tangga utamanya terjadi pada konsumsi pakaian dan alas kaki, serta konsumsi makanan minuman selain restoran yang merupakan kebutuhan konsumsi utama masyarakat menjelang Ramadhan dan Idul Fitri.

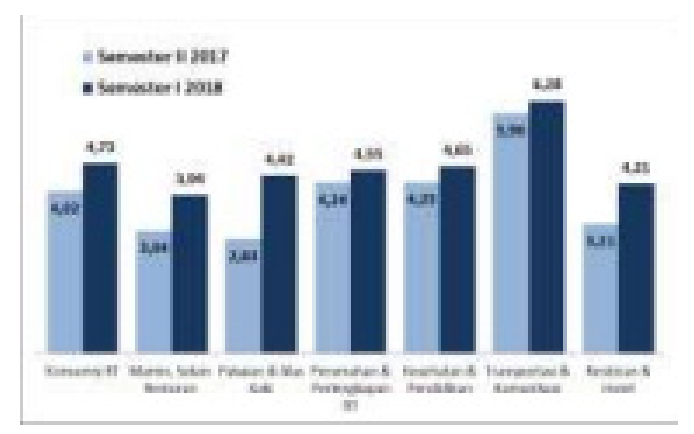

Sumber: BPS (diolah)

Grafik 3. Perkembangan Konsumsi RT Jawa Timur

Sumber: BPS (diolah)

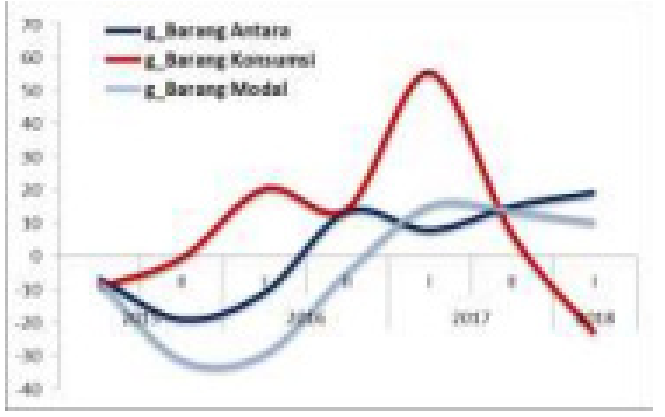

Grafik 4. Perkembangan Impor Jawa Timur

Peningkatan Konsumsi Jawa Timur diindikasi dipenuhi dari produksi domestik. Pertumbuhan impor luar negeri khususnya untuk barang konsumsi, pada semester I 2018 turun signifikan, sedangkan impor barang antara yang merupakan salah satu komponen bahan baku industri meningkat. Peningkatan permintaan domestik, direspon melalui peningkatan produksi lokal oleh sektor industri pengolahan seiring dengan kenaikan kebutuhan bahan baku industri. Hal ini juga tercermin dari peningkatan kinerja industri pengolahan pada paruh pertama $2018 .^{2}$

\section{Sisi Sektoral}

Dari sisi sektoral, perlambatan kinerja ekonomi Jawa Timur pada paruh pertama 2018 disebabkan oleh deselerasi kinerja pertanian. Lapangan usaha pertanian mengalami penurunan pertumbuhan yaitu $-3,12 \%$ (yoy) pada semester I 2018, jauh lebih rendah dibandingkan semester II 2017 maupun periode yang sama di tahun 2017.

Tabel 2. Pertumbuhan Ekonomi Sisi Penawaran/Sektoral (\%,yoy-Tahun Dasar 2010)

\footnotetext{
2 Pertumbuhan impor bahan antara/bahan baku : dari 15,28\% pada semester II 2017 menjadi 19,37\% pada semester I 2018 Pertumbuhan impor barang konsumsi : dari 6,82\% pada semester II 2017 menjadi -23,00\% pada semester I 2018 Pertumbuhan impor barang modal : dari 13,71\% pada semester II 2017 menjadi 10,46\% pada semester I 2018
} 


\begin{tabular}{ccccccccccc}
\hline & 2015 & 2015 & 2016 & 2016 & 2017 & 2017 & 2018 \\
$\mathrm{I}$ & $\mathrm{I}$ & & $\mathrm{I}$ & $\mathrm{I}$ & & $\mathrm{I}$ & $\mathrm{I}$ & & $\mathrm{I}$ \\
\hline
\end{tabular}

Pertanian, Kehutan-

\begin{tabular}{lcccccccccc} 
an, dan Perikanan & 3,32 & 3,23 & 3,28 & 2,26 & 2,56 & 2,41 & 1,25 & 1,72 & 1,48 & $-3,12$ \\
\hline $\begin{array}{l}\text { Pertambangan dan } \\
\text { Penggalian }\end{array}$ & 5,80 & 10,07 & 7,96 & 10,20 & 17,91 & 14,18 & 10,67 & 4,68 & 7,47 & 4,03 \\
\hline $\begin{array}{l}\text { Industri Pengolahan } \\
5,49\end{array}$ & 5,76 & 5,63 & 4,29 & 4,59 & 4,44 & 4,72 & 6,64 & 5,69 & 6,84 \\
\hline $\begin{array}{l}\text { Pengadaan Listrik } \\
\text { dan Gas }\end{array}$ & $-0,46$ & $-3,47$ & $-1,98$ & $-0,46$ & 1,75 & 0,64 & $-1,43$ & 6,56 & 2,58 & 2,29 \\
\hline
\end{tabular}

Pengadaan Air,

Pengelolaan Sampah,

Limbah dan Daur

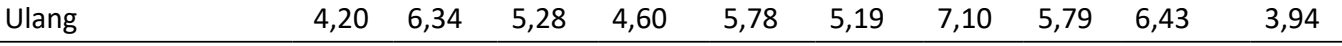

\begin{tabular}{lcccccccccc}
$\begin{array}{l}\text { Konstruksi Perdagan- } \\
\text { gan Besar dan Eceran }\end{array}$ & 2,66 & 4,42 & 3,60 & 7,34 & 3,92 & 5,51 & 6,96 & 6,87 & 6,91 & 7,10 \\
\hline $\begin{array}{l}\text { Reparasi Mobil dan } \\
\text { Sepeda Motor }\end{array}$ & 6,11 & 5,04 & 5,55 & 6,04 & 5,59 & 5,81 & 6,13 & 6,37 & 6,26 & 6,76 \\
\hline $\begin{array}{l}\text { Transportasi dan } \\
\text { Pergudangan }\end{array}$ & 6,46 & 6,88 & 6,68 & 6,70 & 4,76 & 5,71 & 5,30 & 7,89 & 6,62 & 7,81 \\
\hline
\end{tabular}

Penyediaan Ako-

modasi dan Makan

\begin{tabular}{|c|c|c|c|c|c|c|c|c|c|c|}
\hline Minum & 7,15 & 8,24 & 7,72 & 9,54 & 7,53 & 8,49 & 8,85 & 7,04 & 7,91 & 8,54 \\
\hline $\begin{array}{l}\text { Informasi dan Komu- } \\
\text { nikasi }\end{array}$ & 6,89 & 6,09 & 6,49 & 7,30 & 7,84 & 7,57 & 6,09 & 7,73 & 6,92 & 6,89 \\
\hline $\begin{array}{l}\text { Jasa Keuangan dan } \\
\text { Asuransi }\end{array}$ & 5,45 & 8,86 & 7,19 & 9,22 & 4,93 & 6,99 & 2,57 & 2,32 & 2,44 & 5,47 \\
\hline Real Estate & 5,28 & 4,68 & 4,97 & 5,72 & 4,74 & 5,22 & 3,10 & 4,70 & 3,91 & 6,77 \\
\hline Jasa Perusahaan & 5,82 & 5,08 & 5,44 & 4,72 & 5,62 & 5,18 & 5,49 & 5,57 & 5,53 & 7,19 \\
\hline $\begin{array}{l}\text { Administrasi Pemer- } \\
\text { intahan, Pertahanan } \\
\text { dan Jaminan Sosial }\end{array}$ & 4,59 & 5,81 & 5,24 & 7,70 & 2,23 & 4,74 & 2,92 & 1,59 & 2,22 & 6,49 \\
\hline Jasa Pendidikan & 8,54 & 4,77 & 6,53 & 7,52 & 4,55 & 5,97 & 4,23 & 3,76 & 3,99 & 5,42 \\
\hline $\begin{array}{l}\text { Jasa Kesehatan dan } \\
\text { Kegiatan Sosial }\end{array}$ & 6,37 & 6,55 & 6,46 & 5,38 & 6,08 & 5,74 & 6,08 & 4,75 & 5,39 & 7,85 \\
\hline Jasa lainnya & 5,31 & 4,45 & 4,88 & 4,11 & 5,41 & 4,77 & 4,60 & 4,33 & 4,46 & 5,27 \\
\hline PDRB & 5,31 & 5,57 & 5,44 & 5,69 & 5,46 & 5,57 & 5,21 & 5,68 & 5,45 & 5,53 \\
\hline
\end{tabular}

Perlambatan kinerja lapangan usaha Pertanian di Jawa Timur pada periode laporan disebabkan oleh kekeringan yang melanda 199 desa di 23 kabupaten di Jawa Timur. Lebih lanjut, berdasarkan data dari Dinas Pertanian Kabupaten/Kota di Jawa Timur, terdapat penurunan produksi padi, jagung dan hortikultura di beberapa sentra produksi di Jawa Timur. Penurunan produksi padi antara lain terjadi di Kabupaten Pacitan, Kabupaten Nganjuk, dan Kabupaten Tulungagung. Penurunan produksi jagung terjadi di Kabupaten Ponorogo dan Kabupaten Pacitan. Sementara itu, perlambatan pertumbuhan produksi cabai merah dan bawang merah terutama terjadi di Kabupaten Nganjuk.

Perlambatan yang lebih dalam tertahan oleh kinerja lapangan usaha industri pengolahan, perdagangan, dan penyediaan akomodasi. Peningkatan kinerja industri pengolahan (dari 6,64\%,yoy menjadi 6,84\%,yoy) ditopang oleh kenaikan konsumsi domestik sejalan dengan momen Ramadhan, Idul Fitri, dan Pilkada. Berdasarkan kelompok industrinya, akselerasi kinerja lapangan usaha Industri Pengolahan Jawa Timur didorong oleh Industri Manufaktur 
Mikro dan Kecil (IMK) serta Industri Manufaktur Besar dan Sedang (IBS) ${ }^{3}$. Sementara itu, kenaikan kinerja lapangan usaha perdagangan (dari 6,37\%,yoy menjadi $6,76 \%$,yoy) selain didorong oleh peningkatan konsumsi masyarakat, juga karena masih positifnya perdagangan antar daerah. Hal ini juga tercermin dari kenaikan Indeks Riil Perdagangan Eceran (IRPE) hasil Survei Penjualan Eceran Bank Indonesia Provinsi Jawa Timur, khususnya pada kelompok (i) bahan bakar, (ii) peralatan dan komunikasi, serta (iii) barang budaya dan rekreasi. Lebih lanjut, peningkatan kinerja penyediaan akomodasi dan makan minum (dari 7,04\%,yoy menjadi $8,54 \%$,yoy) diantaranya tercermin dari kenaikan konsumsi hotel dan restoran serta kenaikan jumlah wisatawan mancanegara yang berkunjung ke Jawa Timur.

\section{Inflasi}

Pada semester I 2018, Indeks Harga Konsumen (IHK) Jawa Timur mencatat inflasi sebesar 2,67\% (yoy) lebih rendah dibandingkan dengan semester II 2017 yang sebesar 4,04\% (yoy). Rendahnya inflasi tersebut disebabkan oleh cukup terkendalinya inflasi kelompok bahan makanan; makanan jadi; perumahan; serta transpor, komunikasi, dan jasa keuangan. Berdasarkan disagregasi inflasi, terjaganya inflasi disebabkan oleh penurunan inflasi kelompok administered price dan core inflation dibandingkan paruh kedua 2017.

Rendahnya inflasi kelompok administered price (dari 10,69\%,yoy menjadi 2,69\%,yoy) disebabkan utamanya oleh penurunan inflasi tarif listrik. Hal ini seiring dengan hilangnya base effect kenaikan Tarif Dasar Listrik (TDL) yang dimulai pada tahun 2017. Selain itu, penurunan tekanan inflasi administered prices juga disebabkan oleh turunnya tekanan inflasi bensin seiring dengan terkendalinya kenaikan harga BBM non-subsidi pada tahun 2018, yang lebih rendah dibandingkan tahun 2017.

Inflasi inti melambat terutama ditopang oleh perlambatan kelompok core non traded. Inflasi inti pada paruh pertama 2018 sebesar 2,47\% (yoy), lebih rendah dibandingkan semester II 2018 yang sebesar 3,26\% (yoy). Melambatnya inflasi inti tersebut, disebabkan baik oleh inflasi kelompok core traded maupun core non traded, dimana kelompok core non-traded melambat lebih dalam ${ }^{44}$. Penurunan inflasi core traded didorong oleh penurunan harga emas perhiasan secara tahunan sebagai dampak dari penurunan harga emas global dan fluktuasi nilai tukar rupiah dalam beberapa periode waktu terakhir. Sementara itu, penurunan inflasi core non-traded diantaranya disebabkan oleh penurunan tekanan inflasi tarif pulsa telepon seluler seiring dengan berakhirnya dampak peningkatan tarif telepon seluler yang meningkat cukup signifikan pada tahun 2016-2017.

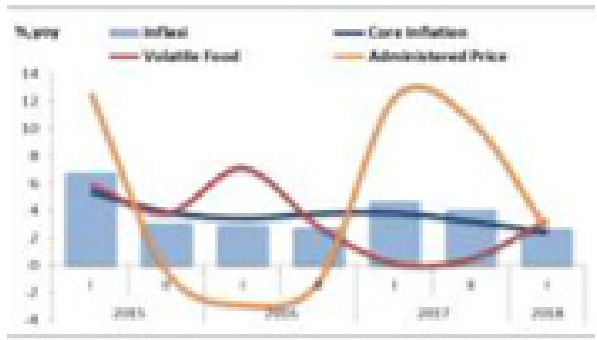

Grafik 5 Perkembangan Inflasi Jawa Timur, 2015- Semester I 2018

\footnotetext{
3 Berdasarkan rilis BPS Provinsi Jawa Timur, IMK tumbuh sebesar 12,7\% (yoy) pada triwulan II 2018. Positifnya kinerja IMK terutama disumbang

oleh pertumbuhan industri: (i) percetakan ( $57,4 \%$ yoy); (ii) kendaraan bermotor ( $37,0 \%$ yoy); (iii) pakaian jadi ( $25,7 \%$ yoy); (iv) furnitur ( $25,6 \%$ yoy); (v) kayu dan barang dari kayu (11,1\% yoy); serta (vi) makanan ( $9,8 \%$ yoy). Sementara, IBS di Jawa Timur tumbuh sebesar $2,1 \%$ (yoy) yang terutama diperani oleh peningkatan kinerja industri: (i) makanan (22,8\% yoy); (ii) farmasi, obat kimia, dan obat tradisonal (14,0\% yoy); (iii) pakaian jadi ( $14,0 \%$ yoy), dan (iv) minuman (10,8\% yoy).

${ }^{4}$ Inflasi kelompok core traded melambat dari 2,41\% (yoy) menjadi 2,02\% (yoy), sedangkan inflasi kelompok core non traded melambat dari 4,06\% (yoy) menjadi 2,87\% (yoy).
} 


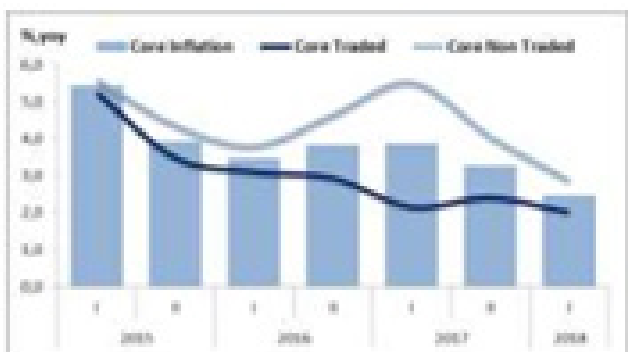

Grafik 6 Perkembangan Inflasi Inti Inflasi Jawa Timur, 2015-Semester I 2018

Inflasi yang lebih rendah tertahan oleh kenaikan inflasi kelompok volatile food. Inflasi kelompok volatile food pada semester I 2018 meningkat (dari 0,53\%,yoy menjadi 3,35\%,yoy), didorong diantaranya oleh kenaikan harga komoditas daging ayam ras, bawang merah dan cabai merah. Peningkatan harga daging ayam ras dikontribusi oleh faktor penurunan produksi karena kondisi cuaca yang kurang mendukung serta kebijakan pelarangan antimicrobial growth promoter (AGP). Selain faktor produksi, kenaikan inflasi kelompok volatile food juga didorong oleh aspek permintaan yang meningkat seiring tingginya konsumsi bahan makanan menjelang Ramadhan dan Idul Fitri.

\section{Perkembangan Stabilitas Sistem Keuangan Daerah}

Stabilitas sistem keuangan Jawa Timur triwulan II 2018 masih terjaga. Kinerja sektor korporasi meningkat, sementara kinerja sektor rumah tangga tetap terjaga. Terjaganya stabilitas keuangan daerah Provinsi Jawa Timur tercermin dari masih positifnya pertumbuhan kredit, terjaganya rasio Non Performing Loan (NPL) di kisaran 3\%, serta masih kuatnya kinerja sektor korporasi dan sektor Rumah Tangga di Jawa Timur.

Pada paruh pertama 2018, pertumbuhan penyaluran kredit perbankan terpantau meningkat. Peningkatan pertumbuhan kredit perbankan (dari 8,38\%,yoy menjadi $8,59 \%$,yoy) utamanya didorong oleh kredit modal kerja (KMK), sedangkan kredit investasi (KI) dan kredit konsumsi (KK) melambat ${ }^{55}$. Tingginya pertumbuhan KMK seiring dengan penurunan suku bunga KMK (dari 10,06\% menjadi 9,85\%) serta tingginya aktivitas ekonomi dunia usaha mempersiapkan kenaikan permintaan domestik menjelang Ramadhan dan Idul Fitri. Sementara itu, walaupun suku bunga KK juga turun, masih terbatasnya konsumsi barang tahan lama masyarakat menahan pertumbuhan KK yang lebih tinggi.

Berdasarkan pelaku ekonomi, kredit korporasi mengalami pertumbuhan yang lebih tinggi dibandingkan kredit Rumah Tangga, dan meningkat dibandingkan semester II 2017 (dari 6,18\%,yoy menjadi 9,77\%,yoy). Peningkatan kredit korporasi utamanya terjadi pada KMK, khususnya lapangan usaha pertambangan dan penggalian, serta industri pengolahan.

Peningkatan KMK ke pertambangan minyak dan gas bumi, sejalan dengan rencana peningkatan cadangan minyak di Lapangan Banyu Urip, Blok Cepu dari 450 juta barel menjadi 729 juta barel untuk memenuhi peningkatan target produksi di tahun 2018 dan 2019. Sementara kenaikan KMK industri pengolahan seiring dengan peningkatan aktivitas industri untuk meningkatkan produksi consumer goods yang merupakan kebutuhan utama masyarakat menjelang Ramadhan dan Idul Fitri.

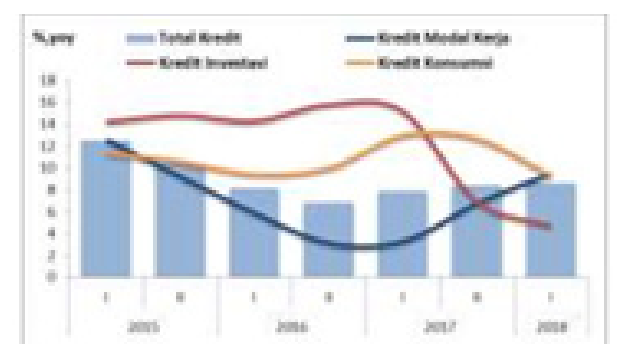

Grafik 7. Pertumbuhan Kredit Perbankan Berdasarkan Jenis Penggunaan (yoy) 


\section{Grafik 8. Pertumbu}

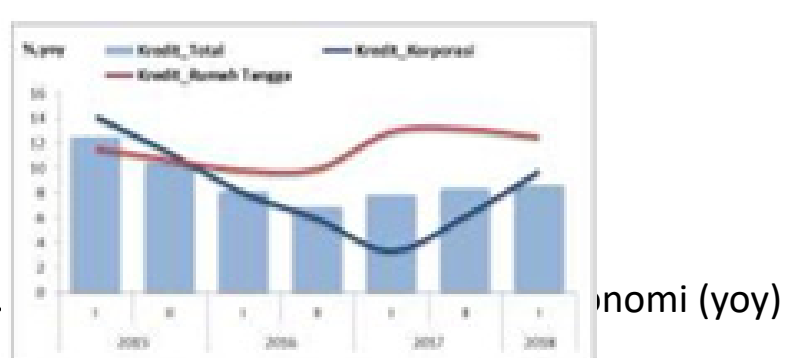

Pertumbuhan Dana Pihak Ketiga (DPK) pada semester I 2018 melambat. Perlambatan DPK (dari 9,61\%, yoy menjadi 8,03\%,yoy) disebabkan oleh deposito, sementara giro dan tabungan meningkat ${ }^{6}$. Berdasarkan pelaku ekonomi, penghimpunan DPK korporasi melambat lebih dalam dibandingkan DPK rumah tangga. Hal tersebut karena tingginya kebutuhan dana korporasi untuk menjalankan aktivitas ekonomi di paruh pertama 2018. Selain itu, penurunan suku bunga DPK korporasi dari 3,12\% menjadi 3,03\% diindikasikan mendorong korporasi lebih memilih menggunakan dananya untuk aktivitas produksi. Di lain sisi, pertumbuhan DPK rumah tangga cenderung stabil karena sektor rumah tangga masih mengalokasikan pengeluarannya untuk menyambut tahun ajaran baru di awal paruh kedua 2018.

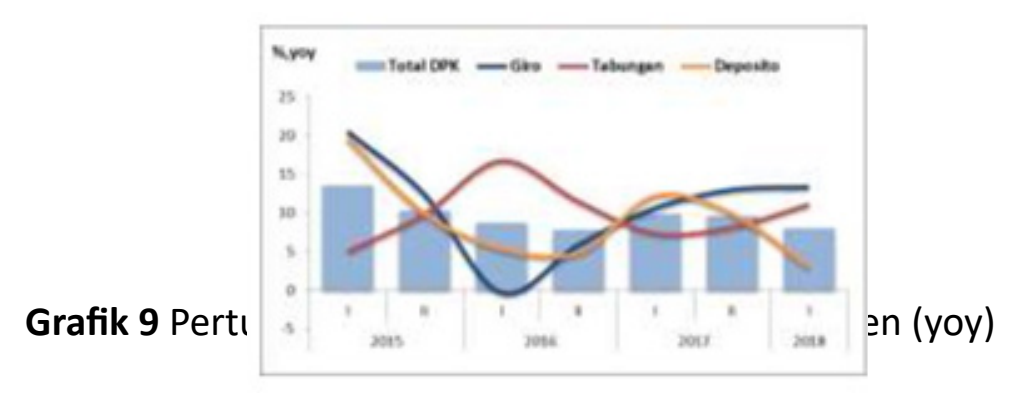

\section{Prospek Perekonomian}

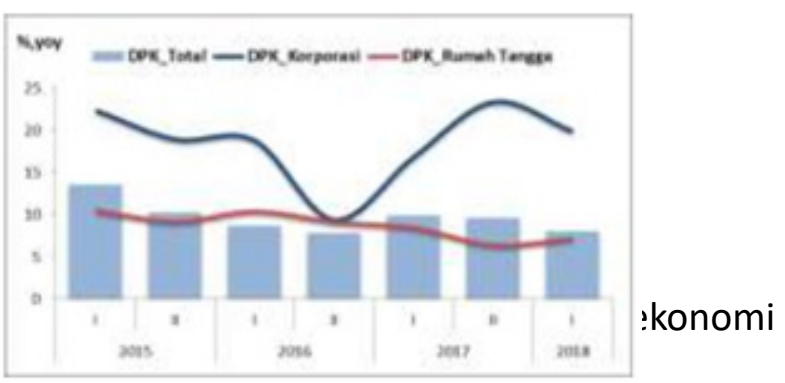

Bank Indonesia memperkirakan perekonomian Jawa Timur pada semester II 2018 tetap tumbuh tinggi ditopang oleh peningkatan permintaan domestik. Tetap tingginya kinerja ekonomi Jawa Timur pada paruh kedua 2018 tersebut searah dengan perkiraan peningkatan konsumsi swasta dan kinerja net ekspor antar daerah sejalan dengan momen Natal dan Tahun Baru. Selain itu, adanya panen gadu untuk komoditas padi dan palawija yang akan berlangsung pada akhir semester II 2018 diperkirakan turut meningkatkan kinerja lapangan usaha pertanian dan ekspektasi penghasilan petani. Lebih lanjut, peran Jawa Timur sebagai sentra pangan dan industri nasional akan turut mendorong kinerja net ekspor antardaerah. Hal tersebut didorong oleh potensi kenaikan permintaan mitra dagang domestik Jawa Timur sejalan dengan peningkatan konsumsi di akhir tahun. Akselerasi yang lebih tinggi diperkirakan tertahan oleh perlambatan investasi, sejalan dengan beberapa proyek infrastruktur yang telah masuk fase penyelesaian.

\footnotetext{
${ }^{6}$ Dibandingkan semester II 2017, pada semester I 2018 pertumbuhan deposito melambat (dari 9,85\%,yoy menjadi 3,00\%,yoy), pertumbuhan giro meningkat (dari 12,99\%,yoy menjadi 13,33\%,yoy), demikian pula dengan pertumbuhan tabungan yang meningkat (dari 8,15\%,yoy menjadi 
Pada semester II 2018, inflasi Indeks Harga Konsumen (IHK) Jawa Timur diperkirakan tetap terkendali dan berada kisaran sasaran inflasi 2018, yaitu $3,5 \pm 1 \%$. Inflasi IHK Jawa Timur pada semester II 2018 diperkirakan sedikit meningkat dibandingkan pencapaian pada paruh pertama 2018. Berdasarkan kelompok pengeluaran, tekanan inflasi pada semester II 2018 diperkirakan bersumber dari kelompok bahan makanan; kelompok transpor, komunikasi, dan jasa keuangan; serta makanan \& minuman, rokok dan tembakau. Sementara berdasarkan disagregasi inflasi, peningkatan inflasi diperkirakan bersumber dari kelompok volatile food dan core inflation. Peningkatan tekanan inflasi kelompok volatile food pada paruh kedua 2018 seiring dengan base effect rendahnya harga pangan pada tahun 2017. Jumlah panen yang melimpah pada tahun 2017, dampaknya belum bisa dirasakan kembali

pada tahun 2018, bahkan ditengarai justru berkurang. Lebih lanjut, peningkatan inflasi pada kelompok core inflation diperkirakan terjadi baik pada aspek demand pull maupun cost push inflation. Di sisi demand pull, adanya Idul Adha, Natal dan Tahun Baru 2019 diperkirakan mendorong konsumsi masyarakat. Sementara dimulainya Tahun Ajaran Baru, diperkirakan mendorong konsumsi dari sisi cost push.

Bank Indonesia akan terus mencermati beberapa risiko dalam perekonomian ke depan. Dari sisi global, divergensi pertumbuhan ekonomi global dan meningkatnya eskalasi ketegangan hubungan dagang antara AS dengan beberapa negara berpotensi menahan pertumbuhan volume perdagangan dunia pada 2018, sehingga berpotensi menahan ekspor Jawa Timur. Lebih lanjut, kenaikan FFR yang cenderung lebih agresif dan diikuti respons kebijakan moneter negara lain untuk mengimbangi kebijakan moneter AS yang ketat berpotensi menarik investasi asing dari Indonesia. Perlambatan pertumbuhan ekonomi Jepang dan Tiongkok, yang merupakan mitra dagang utama Jawa Timur juga berpotensi menahan peningkatan perdagangan internasional Jawa Timur. Dari sisi domestik, potensi terjadinya shortfall pajak dapat menjadi downside risk bagi kinerja konsumsi pemerintah di tahun 2018. Lebih lanjut, peningkatan cukai rokok di tahun 2018 diperkirakan terus memberikan tekanan bagi perusahaan rokok di Jawa Timur yang dapat mempengaruhi performa sektor perdagangan. 